\title{
Los duelos deformados y los crímenes pasionales en las narraciones modernistas mexicanas ${ }^{1}$
}

\author{
Minwook Oh \\ Seoul National University
}

\section{Introducción}

En la Biblioteca Nacional de México, un cronista lee un libro de César Lombroso, el criminólogo-médico italiano (1835-1909), y, entre sus páginas, se topa con una misteriosa carta firmada por un médico llamado Pedro. En ella, Pedro le confiesa a su amigo, un abogado receptor de la carta, los detalles del crimen pasional que cometió. Según la misiva, Pedro ha envenenado a su medio hermano por haber seducido a su esposa. Este es el hilo principal de la historia "El caso de Pedro", el primer cuento del libro Croquis y sepias (1898) escrito por Ciro B. Ceballos (1873-1938), ${ }^{2}$ uno de los escritores modernistas mexicanos más representativos junto con José Juan Tablada, Alberto Leduc, Amado Nervo y Rubén M. Campos. Este cuento de Ceballos condensa el modo en el que los modernistas filtraban y se apropiaban del conocimiento "científico" y de la cultura "decadente", los dos discursos "modernos" importados de las metrópolis europeas. Primero, la escena inicial del cuento destaca la posición privilegiada del narrador. El cronista-narrador en primera persona revela a sus lectores el secreto que supuestamente guardaban dos intelectuales pertenecientes a dos de las profesiones más influyentes (medicina y jurisprudencia) de la sociedad mexicana bajo el régimen de Porfirio Díaz (1877-1880, 1884-1911). Al mismo tiempo que la referencia al libro de Lombroso insinúa la confluencia entre la medicina, la jurisprudencia y la criminología positivistas como discursos hegemónicos de la era porfiriana, esta narración modernista invierte la posición del médico, quien se desplaza de la posición de poder del que analiza, al lugar del objeto de análisis patológico y criminológico. Segundo, aunque esta narración toma una distancia pedagógica al advertir la peligrosidad de la cultura decadente, no escatima su mirada fascinada ante el cuerpo degenerado del médico. Aunque la jerarquía entre la mirada consumidora del sujeto masculino y el cuerpo consumido del objeto femenino se reproduce en varios momentos, el carácter excepcional (un médico que contiene un genio criminal) permite varias interpretaciones potenciales sobre los cuerpos particulares que ya no se adecuan al lenguaje regulatorio.

El presente trabajo va a discutir cómo las narraciones modernistas describen y representan la dinámica entre honor y duelo en los cuerpos degenerados de quienes cometen crímenes pasionales. A fines del siglo XIX

\footnotetext{
1 El presente trabajo retoma y desarrolla algunos aspectos de mi tesis doctoral, Deseos desbordados y cuerpos degenerados: Narrativas modernistas en el fin del siglo XIX mexicano. 2018. Northwestern University, PhD dissertation.

2 Todas las citas de los cuentos de Ceballos están tomadas de esta edición: Ceballos, Ciro. Croquis y sepias. México: Eduardo Dublán, 1898, pp. 1-16.
} 
en México, el honor y la anomalía psiquiátrica funcionaron como atenuantes o catalizadores de la sanción penal en el discurso jurídico y cultural. Al mismo tiempo, esos factores constituyeron el entorno de los ciudadanos decentes y, a la vez, demarcaron el afuera de esa comunidad mediante la exclusión de sujetos que presentaban ciertos matices respecto de la norma, como las mujeres "deshonradas" y los hombres afeminados. A principios del régimen del porfiriato (desde mediados de los setenta hasta los inicios de los noventa), la historia mexicana entró en un momento de estabilización del sistema jurídico y del código penal (Piccato, City 1). Conforme con su lema ideológico "orden y progreso", el grupo de las élites políticas privilegió la estabilidad social antes que la libertad individual en su proyecto nacional como condición para entrar en el umbral del progreso, a diferencia de lo que habían hecho los creadores de la Constitución de 1857 quienes siguieron las ideas liberales clásicas emanadas de la Independencia de Estados Unidos y la Revolución francesa. Además de la estabilidad relativa de la sociedad, las políticas del régimen del porfiriato, que impulsaron la inversión de capital, permitieron a las élites sociales acumular riqueza y aceleraron la urbanización del país. En esa dinámica y ese proceso de modernización, la capital mexicana funcionaba como símbolo del progreso nacional para los países extranjeros y, al mismo tiempo, para el propio pueblo mexicano. Los datos estadísticos en la primera mitad del régimen del porfiriato indicaban una reducción del número de crímenes en la capital. Dichas estadísticas fueron publicitadas por las propias autoridades para mostrar la prueba "objetiva" de la eficacia del régimen. ${ }^{3}$

En la segunda mitad del mandato de Porfirio Díaz, las élites del régimen se enfrentaron a una situación implosiva en la que la tasa de criminales en la capital creció de forma radical, a pesar de que el Estado había impulsado la reforma de las instituciones policiales, penales y carcelarias. ${ }^{4}$ En relación con esta situación, los intelectuales encaminaron su interés hacia la criminología o la antropología criminal, un campo de estudio desarrollado por César Lombroso y sus discípulos europeos. Este grupo de criminólogos buscaba el origen del delito en rasgos biológicos de criminales particulares por medio de una metodología "científica" que observaba sus características fisonómicas

3 Piccato señala el uso arbitrario y paradójico de la estadística de crímenes por las autoridades del régimen en el fin de siglo. Al principio, esos datos "objetivos" no avalaban la premisa a favor del gobierno de que su régimen controlaba de manera efectiva los crímenes urbanos (City 53). Respecto de la concordancia entre los datos y su intención, los datos publicados no mantuvieron una continuidad y las mismas élites intelectuales cuestionaron la credibilidad de esa tasa de criminalidad publicitada por las autoridades.

4 Los datos judiciales de la última década del siglo XIX, según Piccato, muestran un crecimiento drástico de los casos criminales en la Ciudad de México. Los agentes judiciales se quejaban de la falta de una institución adecuada para tratar a esos criminales urbanos:

In 1890, Mexico City's correctional judges complained that arrests are exceeding the capacity of their courts. In 1896, police arrested 29,729 "scandalous drunkards," 94 beggars, and 910 prostitutes. The public attorney stated that whereas 8,108 individuals were convicted in 1897, in 1909 the number had more than doubled to reach 16,318. Figures showed the violent nature of most recorded crimes: between 1885 and 1895, 78 percent of offenses were crimes against persons. Homicide rose from 179 presumed murders arrested in 1891, to 481 in 1895. Figures condemned the Mexican capital as one of the most dangerous cities in the world (City 53-54).

Esa situación, paradójicamente, resultó en una imagen negativa de la capital y requirió de una reforma del sistema judicial. 
desde la frenología. La apropiación de las ideas criminológicas aventajó a las élites mexicanas para mantener su superioridad ética respecto de otras clases "inferiores" que podrían considerarse un patógeno de degeneración social. El argumento de varios criminólogos mexicanos, según Piccato, se fundó sobre un mecanismo común que adoptó las ideas extranjeras y las aplicó en la sociedad mexicana para aislar a los sospechosos, who seemed to depart from modern customs (City 3), de los ciudadanos "decentes". Sin embargo, al mismo tiempo que los criminólogos mexicanos subrayaban la objetividad de su metodología "científica" se fascinaban con la particularidad de los casos observados. En su análisis, la premisa elitista que definía las características de los sujetos "inferiores" -género, raza y clase- y los asimilaba con lo patógeno o los consideraba como síntoma de la degeneración social, evidentemente no podía dar cuenta de todos los casos observados.

El dilema que enfrentaron las élites intelectuales del régimen del porfiriato procedía del principio liberal cuyo objetivo apuntaba hacia un equilibrio imaginado entre igualdad y libertad. 5 En el monismo jurídico del código penal mexicano de fines del siglo XIX, las cuestiones de honor y locura en los crímenes pasionales se enlazaron con el debate acerca de la intervención de las ideas de la medicina, la criminología y las teorías sociales positivistas. El código penal de 1871 fue organizado basándose en la premisa liberal de que los crímenes fueron cometidos bajo el libre albedrío de los criminales. Las ideas de los criminólogos, médicos y juristas positivistas debieron superar ese límite que imponía el principio liberal en el campo jurídico para persistir, desde su posición privilegiada, en la formación de la opinión pública. La cuestión del honor y la herencia biológica engendró frecuentemente un debate controversial en el ámbito judicial respecto del principio liberal y positivista del libre albedrío.

En el marco del contexto ideológico y jurídico del fin de siglo el foco del presente trabajo está puesto en el modo en que los escritores modernistas intervienen en ese dilema enfrentado a las élites políticas (su mayoría es juristas, médicos y criminólogos positivistas) mediante la representación del duelo y la dinámica que se establece entre esta práctica y el honor en los cuerpos degenerados de quienes cometen crímenes pasionales. En primer lugar, el ensayo analiza cómo las narraciones modernistas apropian y cuestionan la imagen de ciencia que, en ese periodo, es sinónimo de ciencia positivista. Aunque se tome en cuenta la influencia del decadentismo europeo en los

\footnotetext{
5 El Estado liberal buscaba un equilibrio ideal entre la libertad y la igualdad. Desde la perspectiva de absolutismo jurídico, los agentes judiciales, según Speckman Guerra, deben ser sancionados por el Estado y el rol de los jueces debe limitarse a la aplicación mecánica a los casos particulares (1418). Ese límite del absolutismo jurídico se asoma de manera más explícita cuando, en los casos judiciales, el entendimiento y la interpretación de un mismo delito divergen en las distintas perspectivas de los agentes jurídicos del tribunal procesal (no solo los jueces, sino también los abogados y el jurado popular). Aunque la inmutabilidad de la ley fue el fundamento ideológico y la dirección principal utilizados para la constitución del Estado liberal a lo largo del siglo XIX, en las prácticas judiciales, el mismo delito codificado no siempre resultó con la misma sanción y esto podría considerarse el intersticio de la norma jurídica para encuadrar todos los casos particulares. Es difícil que la norma jurídica coincida con la particularidad de los casos procesados. Una de las fisuras en el sistema del Estado liberal imaginado por las élites mexicanas finiseculares procedía de la incapacidad de la norma para encuadrar todas las prácticas posibles.
} 
modernistas mexicanos, las narraciones modernistas del crimen pasional, que despliegan varios temas "oscuros" como adulterio, bestialismo y necrofilia, no deberían reducirse a la adaptación pasiva de la moda de las metrópolis europeas. La variedad con que las obras modernistas constituyen las escenas de los crímenes pasionales y sexuales lanza un reto contra las normas jurídicas conformes a la ética burguesa. Sin embargo, las obras modernistas se fundaron sobre el deseo de sus autores, que procuraban reubicar su posición como intelectuales modernos en la sociedad mexicana respecto de las élites de los otros discursos intelectuales. En ese sentido, sus obras siguen la visión positivista que reduce y estereotipa a los personajes, especialmente los sujetos femeninos, representándolos con imágenes estigmatizadas.

\section{El duelo como un ritual moderno para reafirmar la masculinidad decente como atributo de ciudadanía}

La rivalidad entre dos sujetos masculinos por un objeto femenino fue un leitmotiv frecuentemente reproducido en las narrativas modernistas mediante una amplia variedad del evento incitador, desde el adulterio hasta el bestialismo y la necrofilia. En el contexto finisecular de la era porfiriana, la popularidad de las narrativas acerca de la rivalidad pasional reflejó, por un lado, la sensibilidad amenazada de las élites masculinas ante la desestabilización del género convencional y la abstinencia sexual acompañadas por la modernización donde las mujeres empezaron a obtener mayor libertad en el espacio público y los jóvenes se disciplinaron menos según las convenciones tradicionales. Esas narraciones, por otro lado, ofrecieron a sus lectores una oportunidad para imaginar varias maneras de tratar, resolver y agravar el conflicto entre los personajes masculinos como agentes de la rivalidad pasional. Las obras modernistas frecuentemente presentan un desenlace trágico donde el personaje engañado asesina a su rival y/o a la mujer adúltera, en vez de procurar una resolución jurídica. Aunque los personajes engañados por medio del adulterio tuvieran una opción judicial, 6 las obras literarias se limitaron a desarrollar una trama más dinámica, incorporando otras resoluciones como un duelo (formal o informal) a una venganza personal. En vez del procedimiento judicial, la preferencia de la resolución personal por medio de la violencia excesiva y el modo melodramático de las obras literarias modernistas atrajo el interés de los lectores por la impetuosidad narrativa de la trama.

La cuestión del duelo señala, por excelencia y de manera condensada, el dilema de las élites de juristas y legisladores mexicanos en la era porfiriana. Aunque el duelo era un crimen castigado por el Código Penal de 1871, los involucrados eran frecuentemente absueltos en el proceso judicial $y$, muchas

6 El "Código penal para el Distrito Federal y Territorio de la Baja California: sobre delitos del fuero común y para toda la República sobre delitos contra la Federación", codificado en 1871, sancionó el adulterio favoreciendo al hombre casado (en los artículos 816-830). Aunque los casos que involucran a un hombre casado y una mujer libre y a un hombre libre y una mujer casada se penalizan, el caso de la mujer casada que necesita acusar a su marido de adulterio se encuentra limitado a tres condiciones, según el artículo 821: cuando el adulterio se consuma en el domicilio, cuando se comete fuera del domicilio con una concubina y cuando el adulterio genera un escándalo. 
veces, el delito ni siquiera llegaba a la instancia judicial. ${ }^{7}$ En esa disidencia entre la hipotética sanción penal y la práctica judicial había un atributo que marcaba el sujeto civil: el honor. La representación del duelo en las obras modernistas muestra, por un lado, cómo ese ritual moderno reafirmó la posición privilegiada de las élites sociales y, por otro lado, la presencia de la solidaridad entre los participantes masculinos.

En el número correspondiente a la segunda quincena de septiembre de 1901 de la Revista Moderna apareció "! A la muerte...!", un cuento de Rubén M. Campos (1876-1945) que presenta un duelo entre dos oficiales militares. La voz narrativa en tercera persona inicia la trama con una escena donde el protagonista, el capitán Héctor Flor, ve a su esposa Carmen en la alcoba de su casa junto al alférez militar Rodrigo Rubio, su "compañero de infancia y campaña" (86). En esta escena, la descripción de la fraternidad entre los dos personajes masculinos se acompaña con el énfasis en la sexualidad femenina estigmatizada por el cuerpo erotizado de Carmen: "y frenética, apasionada, enhiesta y vibrante de amor, con sus rubísimos cabellos sueltos y flotantes, pequeñita y nerviosa, alzada en la punta de los pies, demandaba un beso de la boca esquiva y adorada" (86). Ante la revelación inesperada, los amigos, ahora rivales, pactan un duelo con sable ante otros militares mayores y de rango más alto como testigos. La sexualidad indomable de la mujer es descrita con fascinación por la mirada del narrador masculino, a pesar de que es el catalizador de la destrucción de la amistad masculina y dirige a los contrincantes a un desenlace pasional y fatal.

Antes de describir los detalles del duelo prometido "a la muerte", la voz narrativa se enfoca en la turbación interna del capitán -descrito como "hermoso, noble, audaz, caballeresco, inteligente y joven" (88)- que sufre la doble traición de su esposa y de su mejor amigo. Así, la desesperación de Héctor Flor por el amor hacia Carmen se transforma en cólera hacia su amigo: "iDebía, pues, morir aquel sagaz victorioso, mil veces traidor, a quien hasta un instante había querido como a un hermano!" (88). Según mi lectura, la dinámica del triángulo erótico en esta obra reafirma la amenaza que presenta la sexualidad femenina que desestabiliza la solidaridad masculina que podría considerarse una alegoría del sujeto nacional: las élites militares provistas de una virilidad a toda prueba y del honor. La voz narrativa pone énfasis en la inevitabilidad de la situación trágica, donde el joven oficial debe recurrir al duelo para defender su honor, aunque su adversario había sido su amigo de infancia: "No era una vendetta vulgar la suya, una susceptibilidad de soldado herido en su pundonor, sino una revelación espantosa de su mancilla que tenía el deber de castigar" (87).

Después de la detallada escena del duelo, Carmen, la esposa de Héctor, llega al lugar de la contienda e interviene entre dos hombres heridos. Ante la situación trágica, le revela a Héctor que su relación con Rodrigo había sido un amor no correspondido y que, en realidad, se trataba de una solicitud unilateral por parte de ella (89). Esa confesión de Carmen reafirma la inocencia de Rodrigo y la fidelidad de su amistad. Esto coloca a los dos hombres

7 El Código Penal de 1871 sancionaba el duelo en los artículos 587-614. 
agónicos en una posición de víctimas que participan en un duelo erróneo. Héctor, después de darse cuenta de la fidelidad de su amigo, se arrepiente de su rencor y se disculpa con él. Sin embargo, la escena se complica cuando Rodrigo, en el último momento de su vida, le declara a Héctor su afecto por Carmen: "iNo!... ino quiero engañarte!... i La amo y la adoro!" (90). Al escuchar esa última erupción emocional de su amigo, el capitán traicionado muere.

Esta obra describe el duelo como una pérdida trágica donde los dos jóvenes talentosos que habían compartido una fraternidad íntima se enfrentan apostando sus propias vidas por una mujer infiel, caprichosa y llena de sensualidad. A diferencia de los personajes masculinos que cumplen con el código formal del duelo como un acto para defender su honor o mediante el sacrificio de haber sofocado su deseo adúltero para defender su fidelidad fraterna, el personaje femenino se describe como un sujeto deficiente que carece de autocontrol de su deseo y que provoca el desenlace trágico donde ninguno de los dos adversarios obtiene la victoria ni el amor.

En Masculinity and Male Codes of Honor in Modern France, Robert A. Nye discute la formación del sentido cultural del honor en la sociedad francesa posrevolucionaria y explica que la virtud necesaria para obtener el honor era el autocontrol del mundo interior del sujeto y que se enlazaban con la vida cotidiana. Esto difiere de la edad premoderna donde el honor se adquiría mediante un acto heroico realizado por un aristócrata masculino que tenía la responsabilidad de participar en la batalla por orden de su rey:

The synthetic honor codes that emerged in post-revolutionary society bore the unmistakable stamp of bourgeois values; they were deeply influenced by the historic struggles of a vigorous urban elite to establish its independent claims to precedence; they reflected the bourgeois preoccupation with moral discipline, inner values, and with the control of reproduction and sex. But these codes also preserved elements of the feudal past in their requirement that men of honor display personal courage, loyalty, prowess in combat, and gallantry in love (32).

La transformación del sentido cultural del honor se enlazó con la dinámica política a lo largo de siglo XIX, tanto en la historia francesa como en la latinoamericana donde la clase burguesa se apropió de la posición de la élite social que había pertenecido a la aristocracia. En la trayectoria decimonónica hacia el Estado liberal, el significado del honor fue reconstituido como un conjunto de las virtudes burguesas y, al mismo tiempo, como el marcador de la clase burguesa. A diferencia de la época premoderna, cuando la nobleza en tanto marcador de clase era inherente al sujeto y su posición social ya estaba decidida antes del nacimiento sin ninguna relación con lo que hiciera, la clase burguesa enfrentó la necesidad de conseguir un nuevo marcador de clase que le permitiera diferenciarse de las otras clases "inferiores" y que, simultáneamente, le posibilitara instituirse y mantenerse como la clase moral, disciplinaria y controladora del deseo. El honor fue un marco lingüístico, político y cultural que sintetizó esas virtudes burguesas con las que los hombres se disciplinarían a sí mismos. Como señala Cesar 
Braga-Pinto, revisando las ideas de Robert Nye, la reformulación del orden de clase donde la clase burguesa se ubica a sí misma como la élite social a través de la exclusión de otras clases inferiores, desde el principio concibió una fisura en su propia lógica:

However, he is not always consistent in describing how rituals of male honor consolidated bourgeois identity by both appropriating the aristocracy's traditions and excluding -or rather contrasting itself with- the lower classes. To be sure, Nye does refer to the paradox that dueling was believed to be both an exercise in equality reinforcing fraternal group membership and a practice excluding women as well as those individuals whose masculinity was perceived to be deficient (584).

Las mujeres y los hombres "afeminados" son los otros que fueron apuntados para ser excluidos del ámbito de los ciudadanos por el discurso del honor y del duelo en ese periodo. Sin embargo, ante el proyecto de construcción del Estado liberal basado en la libertad y la igualdad como dos principios ideológicos, las élites intelectuales debieron incluir a la mayoría de la sociedad en esa comunidad imaginaria. El duelo, que solo estaba permitido entre los sujetos "honrados", destaca la fisura en la igualdad del Estado liberal que, al excluir a las mujeres y a la clase baja, privilegió a las élites masculinas como agente principal de la sociedad moderna.

El contexto histórico de México a fines del siglo XIX agregó un matiz al sentido político y cultural del duelo. Ese ritual moderno, curiosamente, se consideró un acto moderno que otorgaba a sus participantes una imagen de sujeto moderno. Algunas versiones mexicanas del código del duelo, según Piccato, fueron publicadas como Código nacional mexicano del duelo por Antonio Tovar en 1891, Apuntes sobre el duelo por Vicente E. Manero y Código del duelo, traducido, arreglado y anotado por Joaquín Larralde y Anselmo Alfaro en 1886 ("Politics" 348) y adoptaron la manera "culta" de los duelos europeos. La "tecnología" del duelo, que requiere la condición igualitaria entre los adversarios al igual que el pacto de testigos y un arma, decoró el enfrentamiento violento con la imagen del honor y justificó la impunidad de los adversarios ante la justicia o, por lo menos, funcionó como un atenuante de ese crimen. El duelo fue considerado un acto moderno importado de las metrópolis europeas y, al mismo tiempo, se asimiló a la ciencia positivista: Dueling was modern because it expressed Mexicans' cosmopolitanism and their identification of modernity with the customs of contemporary European elites. The fashion of dueling in Mexico paralleled a similar trend in Italy, France and Germany, where dueling was a visible aspect of public life (Piccato "Politics" 333). Respecto del discurso jurídico y al código penal basados en el liberalismo clásico, que eran despreciados por las élites del régimen del porfiriato porque se consideraba que se fundamentan en la metafísica en lugar de la ciencia moderna, el ejercicio con un arma, ya fuera pistola o espada, para resolver un conflicto entre individuos por medio de la violencia, paradójicamente, se evaluó como una ciencia moderna. Mediante el modelo alemán, el ejército mexicano procuró modernizarse y se consideró al duelo como una cultura importante para 
promover la destreza en el uso de la pistola entre los oficiales. La escena del duelo honroso entre dos oficiales jóvenes en el cuento de Campos reafirma ese código del honor y del duelo. Sin embargo, la apropiación de la cultura de las élites europeas no pudo ser accesible para todo el pueblo mexicano por su condición económica y política. Para aprender a usar un arma como una pistola o un sable se requería capacidad económica. El duelo fue un evento ritual que permitió a las élites políticas monopolizar el honor como requisito para enunciar su opinión pública, como sucedía también en la prensa y en la asamblea política.

\section{Los duelos infames: un reto de imaginación narrativa contra la ética burguesa}

"Dos pasiones trágicas" - publicado en Croquis y sepias de Ciro B. Ceballos y dedicado a Amado Nervo, otro modernista mexicano- cuenta la historia de la rivalidad de cuatro jóvenes y criminaliza el duelo entre dos personajes masculinos. Este cuento ofrece un matiz diferente del ritual moderno y que se diferencia de cómo se representa el duelo en la obra de Campos. A lo largo de "Dos pasiones trágicas", la voz narrativa asumida por un escritor esteta, repetidamente interviene en la trama con su autoevaluación acerca de lo narrado. Desde el comienzo, esta obra despliega una crítica a la credulidad respecto de la observación "objetiva" de las novelas naturalistas. La voz narrativa compara su propia obra con las expectativas de los lectores, llamándolas "novelilla objetiva" (151), señalando su característica "enteramente impersonal" (151). Mediante un tono ambiguo y satírico, el narrador se refiere a la inverosimilitud de los personajes y a eventos melodramáticos de la propia obra y se queja de la limitación de la trama:

Conforme á mi criterio de escritor, á mi apreciación de la belleza como artista, y á los procedimientos literarios que empalman en mis ideas, me parece y creo estúpida una narración en la que como factores principales funjan un frasco de veneno y una estocada de espadachín; pero como antes dije, en este caso soy narrador simple é imparcial de un hecho acontecido, y por eso mismo, irresponsable de las inverosimilitudes que en la secuela del pasional proceso ocurran (152, el énfasis es mío).

Con una pose simuladora, la voz narrativa establece, de manera sutil, una crítica contra el leitmotiv del duelo y del envenenamiento que podrían considerarse un cliché de las narrativas de crímenes pasionales, y se burla de la contradicción que implica la pretensión de objetividad en el campo literario. El narrador contrapone la belleza artística a la objetividad observadora y diferencia la imparcialidad narrativa de la verosimilitud de su obra.

Semejante a sus otras obras donde Ceballos adjudica condiciones "anormales" a los personajes masculinos de clase alta o de las élites intelectuales, Gerardo y Adrián, los protagonistas del relato, son estudiantes de jurisprudencia, uno de los discursos hegemónicos en ese momento junto con la medicina. La narrativa describe la fisonomía de Gerardo y la relaciona con su personalidad: 
El cutis perlino y enfermizo de Gerardo (el mayor), denunciaba el beso maligno de los vientos costeños, en sus pupilas muy negras y dilatadas adivinábase un temperamento bilioso, aunque en sus modales correctos y casi estudiados, se veía al hombre seguro de sí mismo, al que ha subordinado los ímpetus del corazón á los fueros de la inteligencia, aun á consta de sacrificios sobrehumanos. (153)

Por el contrario, la descripción de Adrián es relativamente corta y lo define como "un imberbe boquirrubio y de aspecto casi afeminado" (153). La observación del narrador respecto del cuerpo de Gerardo configura un sujeto masculino discordante entre la herencia biológica y la moralidad adquirida que controla sus ímpetus por medio de la convención social, pero de manera hipócrita. Como señala González Stephan en su análisis sobre el cambio que experimenta la figura de los héroes nacionales representados en las obras literarias finiseculares, "la muerte abrupta y la enfermedad que sellan el término de las vidas de estos (anti)héroes nada modélicos" (29) reflejan la crisis de las élites masculinas en la sociedad latinoamericana: "La representación en sí misma revela una figura en crisis - de contornos inestables, indisciplinada, atravesada por múltiples pasiones, de identidades sexuales imprecisas-, en la que, como en un espejo cóncavo, los nuevos sectores del panorama cultural se proyectan distorsionadamente" (29-30). En una situación en la que la imposición de "géneros literarios didácticos, históricos y biográficos" (25) con una visión tradicional de la literatura nacional no tiene cabida en el cambio social producido por la mercantilización de literatura, los escritores debieron responder con una "nueva economía política de la producción reproductiva: domesticar al hombre para la capitalización de riqueza material a través del trabajo; y domesticar a la mujer como agente de la reproducción demográfica" (25). Respecto de esa dinámica entre el cambio social y la respuesta de los géneros literarios, el duelo y la rivalidad entre los hombres ya no pueden seguir los estereotipos que resaltan una figura "varonil y sana" del sujeto masculino. La solidaridad entre un joven degenerado y otro afeminado en "Dos pasiones trágicas" supera la disidencia de sus personalidades contradictorias: "Un cariño muy sincero unía filialmente á los muchachos, y á fe que era bien rara esa amistad entre dos temperamentos tan diversos como lo eran los suyos" (153). La fraternidad de dos estudiantes que pertenecen a un mismo discurso hegemónico, curiosamente, se describe como una relación anormal por su exceso de fe y amistad. Aunque esa descripción no culmina en una relación sexual entre los dos amigos connota una disposición homoerótica que no se estabiliza hasta que llegan a "enamorar mujeres" (154).

Los jóvenes estudiantes conocen por casualidad a dos damas llamadas Maclovia y Anatolia y se enamoran de esas hermanas de buena fortuna. La voz narrativa también dispone el contraste de las características entre los personajes femeninos. Maclovia era "esbelta, de formas robustas, con tez sonrosada y vellosa como un albaricoque en sazón, ojos verdes, boca sensual y ademanes provocantes" (156). La mirada del narrador hacia el cuerpo sensual del personaje femenino patologiza su naturaleza asumiendo el análisis de "un psicólogo" (156). 
En contraste con esa caracterización típica de la mujer histérica, Anatolia se describe como una mujer caracterizada por la inocencia y la infantilidad, como un territorio "virginal", pero que también es erotizada por la mirada masculina (157). La descripción de ambos personajes femeninos, aunque señala características contradictorias, se constituye mediante la asociación de la fisonomía corporal aunadas a características psicológicas. Sin embargo, la voz narrativa de este cuento ya había utilizado el mismo modo para describir a los personajes masculinos, donde la visualización del cuerpo se confundía con un diagnóstico. La atracción entre Gerardo y Maclovia se debe a su personalidad similar; Adrián y Anatolia también se enamoran. Pero ese periodo de luna de miel de ambas parejas no dura mucho. Debido a su temperamento, Maclovia se dio cuenta de que su pretendiente realmente no la respetaba ni la amaba y empezó a interesarse por el novio de su hermana. Gerardo se fue dando cuenta del hastío que producía en su amante y empezó a tener celos de la relación entre ella y su amigo.

Un día, Adrián vio a su amigo en la recámara de Anatolia y abofeteó a su rival. Los dos amigos pactaron un duelo y decidieron sus testigos. Aunque el duelo entre los dos jóvenes fue preparado por medio del código formal, la voz narrativa no lo describe como un acto de honor: "á la hora convenida presentáronse allí los adversarios y después de las fórmulas en el ridículo caso usuales, procedieron los padrinos á los preliminares del delito" (164). La voz narrativa no describe ese ritual moderno como un evento heroico ni indispensable, sino que reafirma su criminalidad. En comparación con lo que sucede en la historia de Campos, la descripción del duelo es muy breve y su escena destaca la crueldad de ese crimen: "Después de una lucha encarnizada y breve uno de los peleantes rodó á la maleza ensangrentado" (165). Adrián se rindió ante su rival y murió. La caracterización de Gerardo como una figura egoísta se equipara con la estigmatización de la sexualidad excesiva de Maclovia. El temperamento caprichoso de Gerardo y la sexualidad inmanejable de Maclovia catalizan el desenlace fatal de la pareja ideal que representan Adrián y Anatolia.

Cuando llega a la casa de las hermanas después del duelo con Andrés, Gerardo se da cuenta de que alguien murió, ya que la casa está de luto. Maclovia le informa a su examante que su hermana se suicidó con veneno. La voz narrativa finalmente insinúa una relación sexual entre Gerardo y Maclovia, sin que hubiera pasado ni un día de la muerte de las víctimas de su infidelidad. El duelo en esta obra no es una defensa del honor de las élites masculinas, sino un crimen violento producido por el egoísmo y el capricho, aunque haya seguido las reglas que establece su código formal. El narrador cierra su historia con otra referencia satírica a la inverosimilitud de su propia obra: "Tenéis muchísima razón, amigos míos, es muy tarde ya, mi relato tiene inverosimilitudes de aquellas que no puede perdonar una persona de mediana sensatez, pero ya lo he dicho y afirmado, ocurrió el caso tal cual yo lo he referido... iperdonadme si no es de vuestro agrado! (167)".

Lo más revelador de esta obra, desde mi punto de vista, es que la construcción de los personajes se basa en la patología y en la criminología positivistas, pero a lo largo de la obra, la voz narrativa cuestiona su propia caracterización de los personajes y se burla de varios clichés frecuentemente 
reproducidos por las obras finiseculares. El tono satírico de ese cuento apunta principalmente a la asociación entre la observación objetiva y la verosimilitud de la narración. Ante esa reflexión metaficcional, el código del duelo como una práctica cultural que afirmaba la superioridad ética de la clase burguesa colapsa y pone en evidencia su hipocresía por medio de la criminalización del duelo.

La descripción de un duelo deformado para destacar la contradicción de la sociedad burguesa aparece en varias obras de Ceballos con imaginación variada. "La muerta" es un cuento dedicado a Bernardo Couto Castillo, el modernista mexicano que murió joven, publicado en Croquis y sepias. En el relato, Santiago, el hijo de un sepulturero, ha crecido cerca de las tumbas y entre ataúdes por lo que se ha acostumbrado a ver muertos y escenas funerarias. Cuando llegó a la adolescencia, se volvió malvado y cruel. Aunque las condiciones de su crecimiento se describen como el factor que más afectó la formación de su personalidad, la voz narrativa le otorga un matiz ambiguo al describirlo como "vigoroso y fuerte como un atrida" (144), una metáfora que se refiere a una familia de la mitología griega maldecida por el odio entre hermanos. A través de la asimilación entre la herencia y el trabajo de la familia, la referencia mitológica anticipa el acto malvado del protagonista en el avance de la trama: "Debido á que su cultura moral y su educación intelectual eran complemente nulas, sus instintos, entorpecidos hasta el embrutecimiento, lo hacían digno de habitar entre trogloditas" (144).

Un día, durante un lujoso funeral, Santiago y su padre están por enterrar un féretro cuando un joven nervioso ordena abrir el ataúd porque quería ver el cadáver antes de que lo sepultaran. En esa parte, la voz narrativa describe el cuerpo muerto de la mujer de manera peculiarmente estética: "La luz huraña del satélite alumbró fantásticamente el cuerpo de la difunta, un cuerpo joven y de técnica enculturación, un cuerpo nítido como el pecho del cisne de Leda, un cuerpo frío, un cuerpo que al ser contemplado hacia encabritarse á todas las concupiscencias, y al ser tocado las helaba todas..." (146). Al ver ese cuerpo muerto, Santiago tuvo una "revelación de sus virilidades" (146). Después de terminar su trabajo, el sepulturero y su hijo volvieron para robar los diamantes que estaban en el ataúd de la difunta. El padre de Santiago le quita las alhajas y las vestiduras a la muerta y huye ordenándole a su hijo que la entierre, pero la escena toma un giro inesperado. Cuando se va su padre, Santiago viola el cadáver de la muerta. En ese momento, el joven que había mandado a abrir el ataúd en el funeral vuelve y se enfrenta al profanador. Los dos varones pelean y Santiago vence a su rival y lo echa en un agujero vacío. Después, el hijo del sepulturero lleva el cuerpo de la muerta y lo arroja en el mismo lugar que a su rival.

Propongo que este cuento combina dos crímenes pasionales y sexuales: asesinato y necrofilia. Desde el comienzo, la voz narrativa adopta la forma de un análisis criminológico respecto de la condición hereditaria del protagonista y el ambiente en el que este creció. El sepulturero, padre de Santiago, se describe como una persona codiciosa que roba las alhajas de la difunta e involucra a su propio hijo en su acto criminal. Sin embargo, esta 
obra modernista no solo criminaliza la clase baja mediante la caracterización determinista de su profesión, sino que deja un espacio ambiguo de interpretación sobre el acto del joven de clase alta. La voz narrativa no aclara el motivo por el que ese personaje misterioso vuelve al sepulcro de la difunta en la oscuridad nocturna. La escena de la violación necrófila se conecta con la aparición repentina del joven que tuvo intimidad con la difunta. La trama ambigua funciona como un transgresor semiótico de la norma ética y jurídica. Para el joven de clase burguesa, si el motivo de su regreso al sepulcro fuera idéntico al del sepulturero joven, el enfrentamiento con su rival ante la difunta no podría considerarse un acto de defensa de su honor. Mientras la voz narrativa dispone de manera ambigua la rivalidad entre los dos sujetos masculinos, el análisis diagnóstico del protagonista acerca de su anomalía por medio de la predisposición de la teoría de degeneración se desestabiliza. Las élites políticas, después de la Constitución de 1857, se sintieron amenazadas por el principio igualitario que esta norma establecía y que reducía su posición privilegiada como enunciador de opinión pública. El dilema de las élites políticas del porfiriato mostraba que la necesitad del honor como filtro de clase no había sido armónica con el principio del Estado liberal que ellos mismos debieron defender y promover. Aunque el Código Penal de 1871 criminalizó el duelo, la institución judicial casi no lo castigó y los juristas lo justificaron en nombre de la opinión pública. Sin embargo, la impunidad del duelo en la sanción penal engendró una disidencia de opinión entre las élites intelectuales porque no fue coherente con el principio de la estatalización de la ley como condición de igualdad judicial. La diferencia entre el discurso jurídico y la práctica social respecto del honor y al duelo muestra la fisura del sistema moderno basado, por lo menos nominalmente, en los principios de igualdad y libertad.

\section{Conclusión}

En el mismo año de publicación de "El caso de Pedro" de Ciro B. Ceballos -la obra que comenté en la introducción del presente trabajo y que su autor dedicó a José Ferrel (1865-1954), abogado y autor-, en el primer número de la Revista Moderna apareció "La consulta de Pedro", un cuento escrito por Ferrel como una respuesta a la obra que le había sido dedicada. El narrador del cuento de Ferrel es Fabricio, abogado y receptor de la carta de Pedro, quien presenta la historia de su propio matrimonio fracasado y le aconseja a Pedro que confiese su crimen en el tribunal. La voz de jurisperito define el caso de su amigo y diagnostica su característica de criminal: "Tú la preparaste, cumpliendo maquinalmente con una necesidad de tu organismo. No has matado por celos, sino por odio; no procediste por pasión, sino por cálculo" (6). En esta parte del relato, el abogado ubica el crimen de Pedro en un lugar ambiguo entre una condición inevitable y una decisión de libre albedrío. Este comentario señala la dificultad de marcar esos dos factores que principalmente se consideraban dos causas criminales en ese período. Después de su consulta jurídica y crítica moral, Fabricio cuenta su propia historia y el adulterio de su esposa. Fabricio se casó con una mujer alemana a quien le fastidiaba la vida mexicana. El desagrado de la mujer alemana contra la cultura mexicana señala de una manera implícita la relación colonial entre el centro y la periferia. Aunque el jurista se da cuenta de la infidelidad de su mujer abandona la venganza y deja a su esposa sin ninguna violencia. 
Fabricio pide a su esposa que vuelva a Alemania y ella acepta complacida. El abogado, refiriéndose al matrimonio como un "contrato" (7) que "no más que á los que se casan les obliga el notario á hacer la tontería de firmar la escritura social por toda la vida" (7), evalúa su desenlace conyugal como la anulación de contrato comercial: "Así nos separamos, sin violencias, sin tragedias, sin gritos, pacíficamente, como dos comerciantes aburridos de su sociedad que no prospera" (8). La comunicación epistolar entre los dos amigos construye una solidaridad entre las élites intelectuales representativas de la era porfiriana: medicina y jurisprudencia. Sin embargo, ante el adulterio de sus esposas -que se describen como inmanejables-, el médico comete un homicidio con premeditación y el jurista recomienda la separación física como divorcio simbólico.

Ante un cambio radical de la sociedad -la modernización en términos culturales y materiales- los modernistas mexicanos enfrentaron la necesidad de ubicarse como intelectuales modernos en la sociedad moderna. En sus narraciones, en las que los personajes masculinos se enfrentan de manera mortal para obtener a los sujetos femeninos como un trofeo, las voces narrativas toman una posición donde enuncian una modalidad marcada por la "modernidad", un atributo que los ciudadanos decentes deben poseer. Esos modelos ofrecidos por sus narraciones excesivas y melodramáticas se basan en las patologías positivistas y el código de honor que demarcaban la frontera entre los ciudadanos decentes y los inferiores. Al mismo tiempo, estas obras cuestionan esa demarcación para que los modernistas mismos puedan diferenciarse de las élites intelectuales de otros discursos hegemónicos. En consecuencia, estas narraciones tienden a ofrecer una potencialidad artística que les otorga a los escritores una posición de élite intelectual, pero que todavía retoma la retórica estereotipada para representar a los sujetos femeninos porque su proyecto también apunta a una comunidad exclusiva entre hombres.

\section{Obras citadas}

Braga Pinto, Cesar. "Journalists, Capoeiras, and the Duel un NineteenthCentury Rio de Janeiro". Hispanic American Historical Review, vol. 94, No 4, 2014, pp. 581-614.

Campos, Rubén M. "iA la muerte...!" Cuentos completos, 1895-1915, editado por Serge Iván Zaïtzeff, Consejo Nacional para la Cultura y las Artes, 1998, pp. 86-90.

Ceballos, Ciro B. "El caso de Pedro". Croquis y sepias, Eduardo Dublán, 1898, pp. $1-16$.

"Dos pasiones trágicas". Croquis y sepias, México: Eduardo Dublán, 1898, pp. 151-167.

"La muerta". Croquis y sepias, México: Eduardo Dublán, 1898, pp. 141-150.

Ferrel, José. "La consulta de Pedro". Revista Moderna, No 1, 1898, pp. 6-8. González Stephan, Beatriz. "Héroes nacionales, estado viril y sensibilidades homoeróticas". Entre hombres: masculinidades del siglo XIX en América Latina, editado por Ana Peluffo e Ignacio M. Sánchez Prado, Iberoamericana-Vervuert, 2010, pp. 23-58. 
Nye, Robert. Masculinity and Male Codes of Honor in Modern France. Oxford UP, 1993.

Oh, Minwook. Deseos desbordados y cuerpos degenerados: Narrativas modernistas en el fin del siglo XIX mexicano. 2018. Northwestern U, PhD dissertation.

Piccato, Pablo. City of Suspects: Crimes in Mexico City, 1900-1931. Duke UP: 2001.

"Politics and the Technology of Honor: Dueling in Turn-of-the-Century Mexico". Journal of Social History, vol 33, No 2, 1999, pp. 331-54.

Speckman Guerra, Elisa. "Los jueces, el honor, y la muerte. Un análisis de la justicia (ciudad de México, 1871-1931)". Historia Mexicana, vol. LV, No 4, 2006, pp. 1411-66. 